\title{
PENGARUH IMPLEMENTASI RELATIONSHIP MARKETING TERHADAP LOYALITAS PELANGGAN PRODUK INDIHOME PADA PT. TELKOM INDONESIA CABANG PADANGSIDIMPUAN
}

\author{
Nida Amalia ${ }^{1}$, Fatahuddin Aziz Siregar ${ }^{2}$, Aliman Syahuri Zein ${ }^{3}$ \\ ${ }^{1}$ Mahasiswa IAIN Padangsidimpuan \\ ${ }^{2,3}$ Dosen IAIN Padangsidimpuan
}

\begin{abstract}
The problem of this research is motivated by PT. Telkom Indonesia has implemented good relationship marketing with customers at the beginning of using Indihome products. However, many customers still do not heed the rules. This is because many customers submit network complaints that sometimes experience interference, the delay in paying bills even states the inability to pay bills after using Indihome products to finally decide not to subscribe again. The purpose of this study is to determine whether relationship marketing has a significant influence on customer loyalty of Indihome products at PT. Telkom Indonesia, Padangsidimpuan Branch. The discussion in this study relates to economics, especially business management. In connection with that, the approach taken is theories relating to customer loyalty, relationship marketing, communication, commitment and handling complaints. This research is a quantitative study using multiple linear regression analysis. The technique of collecting data using a questionnaire with a sample of 97 customers with the sampling technique is Random Sampling. Data processing is done with SPSS version 22. The results of this study show partially that communication has no effect on customer loyalty with tcount <ttable $(1.511<1.661)$, commitment has an influence on customer loyalty with tcount> ttable (4.230>1.661), complaint handling has an influence on customer loyalty with value $t$ count $>$ t table $(2.525>1.661$. Based on the simultaneous test results that communication, commitment, complaint handling have an influence on customer loyalty with Fcount> Ftable (37,477> 2,14). Based on the test results the coefficient of determination can be seen that $54.7 \%$ variable communication, commitment, complaint handling affect customer loyalty and the remaining $45.3 \%$ is influenced by other variables not discussed in this study.
\end{abstract}

Keywords: Relationship Marketing, Customer Loyalty 
At-tijaroh Volume 3 No.2, Desember 2017

\section{PENDAHULUAN}

Era globalisasi dalam segala bidang termasuk dalam bidang ekonomi, memberikan dampak terhadap sebuah negara. Berbagai peristiwa di dunia dalam waktu yang singkat dapat diketahui dengan menggunakan satelit dan jaringan informasi yang serba canggih. ${ }^{1}$ Melihat kebutuhan informasi tersebut, PT. Telkom Indonesia memiliki produk di seluruh Indonesia yaitu Indihome sebagai bagian layanan informasi bagi masyarakat. Salah satu PT. Telkom yang ada di Indonesia adalah PT. Telkom Indonesia Cabang Padangsidimpuan yang juga memiliki produk yang sama yaitu Indihome.

Indihome adalah singkatan dari Indonesian Digital Home berupa paket layanan internet (internet on fiber atau high speed internet), layanan televisi interaktif (Usee TV cable, IP TV) dan telepon rumah (voice). Indihome memiliki kelebihan diantaranya jaringan internet yang super cepat, kualitas gambar yang tinggi (high definition) serta kualitas layanan telepon yang jernih. ${ }^{2}$ Namun dengan berbagai kelebihan tersebut, ternyata masih kurang didukung dengan pelanggan yang loyal. Berdasarkan informasi yang diperoleh melalui hasil wawancara dengan Ibu Tettiana Dongoran selaku supervisor pelayanan plasa mengatakan bahwa, masih banyak pelanggan menyampaikan keluhan terkait dengan gangguan pada jaringan, keterlambatan dalam membayar tagihan bahkan menyatakan ketidakmampuan membayar tagihan setelah memakai produk Indihome hingga akhirnya memutuskan untuk tidak berlangganan kembali. PT. Telkom Indonesia Cabang Padangsidimpuan sudah memberikan syarat dan informasi di awal penggunaan produk Indihome. Namun, tetap saja banyak pelanggan yang tidak mengindahkan syarat yang ditetapkan oleh PT. Telkom Indonesia. ${ }^{3}$

Adanya pemutusan hubungan untuk tidak berlangganan kembali menunjukkan bahwa pelanggan Indihome tidak loyal karena loyalitas pelanggan secara umum dapat dinilai berdasarkan lamanya pelanggan dalam menggunakan produk atau jasa serta kesetiaan pelanggan untuk tidak berpaling ke produk lain. Loyalitas pelanggan juga dapat dilihat berdasarkan perilaku penggunaan produk atau jasa karena nasabah yang loyal biasanya akan

\footnotetext{
${ }^{1}$ Buchari Alma dan Donni Juni Priansa, Syariah Marketing (Bandung : CV. Alfabeta, 2009), hlm. 273.

${ }^{2}$ Kelebihan Indihome Fiber (https://my.telkom.co.id/, diakses 10 Oktober 2016 pukul 13.00 WIB).

${ }^{3}$ Tettiana Dongoran, Supervisor Plasa PT. Telkom Indonesia Cabang Padangsidimpuan wawancara di Plasa Telkom Padangsidimpuan, 29 Oktober 2016 pukul. 14.00 WIB.
} 
Pengaruh...... Nida Amalia, Fatahuddin Aziz Siregar dan Aliman Syahuri Zein

menggunakan produk atau jasa secara berulang dan teratur, menggunakan antar lini produk atau jasa, mereferensikan kepada orang lain serta menunjukkan kekebalan terhadap tarikan dari pesaing.

Untuk meminimalisir masalah yang terjadi, PT. Telkom Indonesia Cabang Padangsidimpuan telah berupaya menerapkan relationship marketing. Hal ini juga diwujudkan dengan adanya Peringatan Hari Pelanggan yang diadakan pada setiap tanggal 4 September setiap tahunnya. Hal ini juga dilakukan untuk membangun hubungan yang erat antara PT. Telkom Indonesia dengan pelanggan sebagai wujud rasa terimakasih dan penghargaan terhadap pelanggan.

Loyalitas adalah hasil dari menjalin hubungan baik dengan pelanggan dalam jangka panjang. Untuk mendapatkan pelanggan yang loyal tentunya perusahaan harus mempunyai strategi. Loyalitas pelanggan harus dibangun dengan usaha keras dimana pelanggan menjadi inti dari aktivitas pemasaran, sehingga dengan adanya strategi relationship marketing berupaya memperpanjang umur hidup pelanggan sebagai individu yang bertransaksi. Semakin aman atau nyaman seorang pelanggan berinteraksi dengan penyedia layanan, maka pelanggan tersebut semakin setia kepada penyedia layanan. ${ }^{4}$

Relationship Marketing, yaitu upaya untuk melibatkan, menciptakan, mempertahankan dan mendorong hubungan jangka panjang dengan para pelanggan dan juga pihak-pihak lainnya untuk keuntungan bersama. ${ }^{5}$ Seorang pelanggan yang loyal adalah aset yang sangat bernilai dan merupakan kekuatan dalam menghalangi pemain baru masuk (barrier to new entrants) bagi perusahaan. Untuk itu, Perusahaan haruslah mempertahankan pelanggan yang loyal agar nantinya pelanggan ini dapat memberikan informasi terkait dengan produk perusahaan. Karena promosi yang dilakukan dari mulut kemulut (word of mouth) terkadang jauh lebih efektif dibandingkan promosi yang dilakukan dimedia seperti televisi, koran maupun radio. Namun untuk mendapatkan pelanggan yang loyalitas tentunya tidaklah mudah. Dikarenakan sikap setiap pelanggan yang berbeda-beda. Sikap juga merupakan salah satu konsep yang paling penting yang digunakan pemasar untuk memahami konsumen. ${ }^{6}$

\footnotetext{
${ }^{4}$ Morissan, Periklanan : Komunikasi Pemasaran Terpadu (Jakarta: Kencana, 2010), hlm. 5.

${ }^{5}$ Ibid., hlm. 4.

${ }^{6}$ Nugroho Setiadi, Perilaku Konsumen (Jakarta: Kencana, 2010), hlm. 139.
} 
At-tijaroh Volume 3 No.2, Desember 2017

Loyalitas pelanggan terhadap suatu produk dan jasa berkaitan dengan konsep Relationship Marketing dilandasi oleh faktor-faktor tertentu. Patria Sorce menyebutkan, beberapa faktor yang menentukan relationship marketing, diantaranya commitment, trust, power, control, balance of power, interdependence, communication, cooperation, idiosyncratic investments, dan conflict resolution. ${ }^{7}$ Dari faktor-faktor relationship marketing di atas, maka peneliti hanya menggunakan 3 variabel bebas yaitu komunikasi, komitmen dan penanganan keluhan dikarenakan variable tersebut lebih dominan dilakukan oleh PT. Telkom Indonesia Cabang Padangsidimpuan. PT. Telkom Indonesia Cabang Padangsidimpuan selalu berupaya untuk berkomunikasi dengan pelanggan secara sederhana, ramah dan santun. Sehingga pelanggan dapat dengan mudah memperoleh informasi. PT. Telkom Indonesia Cabang Padangsidimpuan juga berkomitmen agar semua lapisan masyarakat dapat memperoleh informasi melalui produk Indihome. Sesuai dengan slogan perusahaan "Dunia Dalam Genggaman" (world in your hand). Selain itu, penanganan keluhan yang adil selalu diupayakan terjadi agar pelanggan tetap setia kepada perusahaan. Pelanggan juga diberikan kemudahan untuk menyampaikan keluhan melalui Call Center 147 selama 24 jam, surat keluhan pelanggan atau bisa datang langsung ke PT. Telkom Indonesia Cabang Padangsidimpuan.

Dengan demikian, maka tujuan dari penelitian ini adalah: Untuk mengetahui pengaruh komunikasi terhadap loyalitas pelanggan produk Indihome pada PT. Telkom Indonesia Cabang Padangsidimpuan, untuk mengetahui pengaruh komitmen terhadap loyalitas pelanggan produk Indihome pada PT. Telkom Indonesia Cabang Padangsidimpuan, untuk mengetahui pengaruh penanganan keluhan terhadap loyalitas pelanggan produk Indihome pada PT. Telkom Indonesia Cabang Padangsidimpuan dan untuk mengetahui pengaruh komunikasi, komitmen dan penanganan keluhan mempunyai pengaruh terhadap loyalitas pelanggan produk Indihome pada PT. Telkom Indonesia Cabang Padangsidimpuan secara simultan.

\section{KAJIAN TEORITIS}

${ }^{7}$ Patricia Sorce, Relationship Marketing Strategy Research (New York: Rochester Institute of Technology, 2002), hlm. 16. 
Perusahaan yang berorientasi pada pasar harus memfokuskan perhatian mereka pada upaya untuk mempertahakan hubungan selama mungkin dengan pelanggan. Upaya ini mendorong perusahaan untuk menmberikan perhatian pada apa yang disebut Relationship Marketing, yaitu upaya untuk melibatkan, menciptakan, mempertahankan dan mendorong hubungan jangka panjang dengan para pelanggan dan juga pihak-pihak lainnya untuk keuntungan bersama. ${ }^{8}$

Dalam Islam, manusia juga sangat dianjurkan agar memelihara hubungan dengan baik. Sebagaimana firman Allah dalam $Q S$. An-nisā ayat 1 yang berbunyi:

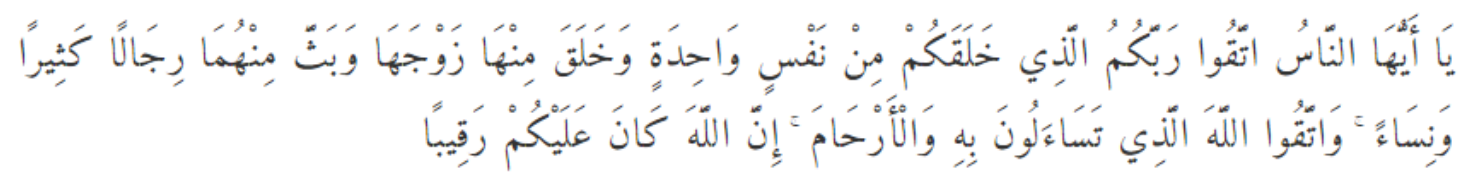

Artinya: Hai sekalian manusia, bertakwalah kepada Tuhan-mu yang telah menciptakan kamu dari seorang diri, dan dari padanya Allah menciptakan isterinya; dan dari pada keduanya Allah memperkembang biakkan laki-laki dan perempuan yang banyak. Dan bertakwalah kepada Allah yang dengan (mempergunakan) nama-Nya kamu saling meminta satu sama lain, dan (peliharalah) hubungan silaturrahim. Sesungguhnya Allah selalu menjaga dan mengawasi kamu.

Penggalan ayat ini mengantarkan lahirnya persatuan dan kesatuan dalam masyarakat serta bantu- membantu dan saling menyayangi. Semua dituntut untuk untuk menciptakan kedamaian dan rasa aman dalam masyarakat dan saling menghormati hak azasi manusia karena Allah akan selalu mengawasi hamba-Nya. ${ }^{9}$ Dengan terjalinnya silaturahmi maka akan menimbulkan dampak psikologis tersendiri, yaitu kedekatan emosional yang terbina dengan baik. ${ }^{10}$

Barnes menambahkan dalam buku manajemen pemasaran bank syariah, bahwa salah satu unsur fundamental dari Relationship Marketing dengan pelanggan adalah fokus pada ketahanan pelanggan. Unsur lain adalah penghargaan terhadap nilai seorang pelanggan. Tujuan hubungan yang sejati dengan pelanggan adalah kepuasan jangka panjang yang melampau transaksi individual. ${ }^{11}$

${ }^{8}$ Morissan. Loc., Cit.

${ }^{9}$ M. Quraish Shihab, Tafsir Al-Misbah (Jakarta: Lentera Hati, 2002), hlm. 314.

${ }^{10}$ Herry Sutanto dan Khaerul Umam, Manajemen Pemasaran Bank Syariah (Bandung: Pustaka Setia, 2013), hlm. 301-302.

${ }^{11}$ Ibid., hlm. 236. 
At-tijaroh Volume 3 No.2, Desember 2017

Beberapa faktor yang menentukan relationship marketing, diantaranya commitment, trust, power, control, balance of power, interdependence, communication, cooperation, idiosyncratic investments, dan conflict resolution. Dari faktor-faktor relationship marketing di atas, maka peneliti hanya menggunakan 3 variabel bebas yaitu komunikasi, komitmen dan penanganan keluhan dikarenakan variabel tersebut lebih dominan dilakukan oleh PT. Telkom Indonesia Cabang Padangsidimpuan

\section{Komunikasi}

Komunikasi adalah proses pemindahan pengertian dalam bentuk gagasan atau informasi dari seseorang ke oranglain. Perpindahan pengertian tersebut melibatkan lebih dari sekedar kata-kata yang digunakan dalam percakapan, tetapi juga ekspresi wajah, intonasi, titik putus vokal dan sebagainya. Dan perpindahan yang efektif memerlukan tidak hanya transmisi data, tetapi bahwa seseorang mengirimkan berita dan menerimanya sangat tergantung pada keterampilan-keterampilan tertentu (membaca, menulis, mendengar, berbicara dan lain-lain) untuk membuat sukses pertukaran informasi. ${ }^{12}$ Komunikasi juga dapat sebagai pengingat bagi konsumen mengenai keberadaan produk yang pada masa lalu pernah dilakukan transaksi pada produk itu.

Komunikasi terjadi dalam hubungan pengirim dan penerima. Komunikasi dapat mengalir satu arah dan berakhir disana atau sebuah pesan dapat menimbulkan respon secara formal yang dikenal dengan nama umpan balik dari penerima. Adapun proses komunikasi sebagai berikut $:^{13}$

\section{Gambar 2.1}

\section{Proses Komunikasi}

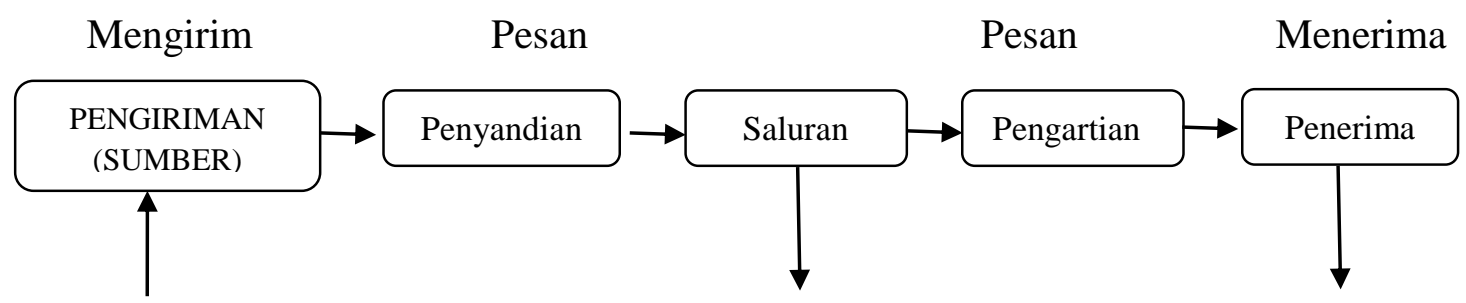

\footnotetext{
${ }^{12}$ T. Handoko, Manajemen, Edisi Kedua Cet: Kesepuluh (Yogyakarta: BPFE, 2009), hlm. 272.

${ }^{13}$ Nugroho J Setiadi, Op. Cit., hlm. 65
} 
Pengaruh..... Nida Amalia, Fatahuddin Aziz Siregar dan Aliman Syahuri Zein

Menerima

Gangguan

Mengirimkan

a) Pengirim atau sumber pesan Mengawali komunikasi. Dalam sebuah organisasi, pengirim dapat berupa seseorang dengan informasi, kebutuhan, atau keinginan dan dengan tujuan mengomunikasikan kepada satu atau beberapa orang lain.

b) Penerima adalah orang yang indranya menerima pesan dari pengirim. Pesan harus disesuaikan dengan latarbelakang sipenerima. Bila pesan tidak sampai pada penerima, komunikasi tidak akan terjadi. Situasi itu tidak banyak diperbaiki bila pesan mencapai penerima tidak memahaminya. Tiga faktor yang dapat mempengaruhi komunikasi efektif dan tidak efektif adalah penyandian, pengartian, dan gangguan.

c) Penyandian, terjadi ketika pengirim menerjemahkan informasi untuk dikirimkan menjadi serangkaian simbol. Penyandian itu perlu karena informasi hanya dapat dikirimkan dari seseorang kepada oranglain lewat perwakilan atau simbol. Karena komunikasi merupakan objek dari penyandian, pengirim berusaha menetapkan arti yang dipahami bersama dengan penerima dengan cara memilih simbol. $^{14}$

d) Saluran, pilihan komunikator terhadap media atau saluran distribusi. komunikasi lisan mungkin disampaikan melalui berbagai saluran, telepone, mesin pendikte, orang atau videotape. Hal ini dilakukan secara pribadi arau dalam pertemuan kelompok dengan orang banyak. Dalam kenyataannya, salah satu keputusan penting yang harus dibuat pengirim adalah dalam penentuan saluran yang tepat.

e) Pengartian, proses yang dilakukan oleh penerima untuk menginterpretasikan pesan dan menerjemahkannya kedalam informasi yang mempunyai arti. Ini merupakan proses dua langkah. Pertama, penerima harus menerima pesan itu, kemudian mengartikannya. Pengartian dipengaruhi oleh pengalaman penerima, penilaian pribadi mengenai simbol dan gerak tubuh yang dipakai, harapan, dan kesamaan arti dengan pengirimnya.

Perilaku konsumen adalah dinamis, berarti bahwa perilaku seorang konsumen, grup konsumen, ataupun masyarakat luas selalu berubah dan bergerak sepanjang waktu. Sikap

${ }^{14}$ Ibid., hlm. 165-166. 
At-tijaroh Volume 3 No.2, Desember 2017

konsumen bisa merupakan sikap positif ataupun negatif terhadap produk-produk tertentu. Dengan mempelajari keadaaan jiwa dan keadaan pikir dari seseorang diharapkan dapat menentukan perilaku konsumen. ${ }^{15}$ Adapun faktor-faktor yang mempengaruhi konsumen sebagai berikut :

a) Faktor kebudayaan

(1) Kebudayaan

Kebudayaan merupakan faktor penentu keinginan dan perilaku seseorang yang paling mendasar. Bila makhluk-makhluk lainnya bertindak berdasarkan naluri, maka perilaku manusia umumnya dipelajari. Dengan kata lain, merupakan faktor yang paling utama dalam perilaku pengambilan keputusan konsumen.

(2) Sub budaya

Setiap kebudayaan terdiri dari subbudaya-subbudaya yang lebih kecil yang memberikan identifikasi dan sosialisasi yang lebih spesifik untuk para anggotanya. Subbudaya dapat dibedakan menjadi empat jenis: kelompok nasionalisme, kelompok keagamaan, kelompok ras, kelompok geografis.

(3) Kelas Sosial

Kelas-kelas sosial adalah kelompok yang relatif homogen dan bertahan lama dalam suatu masyarakat, yang tersusun secara hiraerki dan keanggotaannya mempunyai nilai, minat, dan perilaku serupa. ${ }^{16}$

b) Faktor sosial

(1) Kelompok Referensi

Kelompok referensi seseorang terdiri dari seluruh kelompok yang memiliki pengaruh langsung (tatap muka) maupun tidak langsung terhadap sikap atau perilaku seseorang. Kelompok yang memiliki pengaruh langsung terhadap seseorang dinamakan kelompok keanggotaan. Beberapa kelompok

\footnotetext{
${ }^{15}$ Basu Swastha Dharmesta dan T. Hani Handoko, Manajemen Pemasaran Bank: Analisis Perilaku Konsumen (Yogyakarta: BPFE Yogyakarta, 2016), hlm. 94.

${ }^{16}$ Nugroho J Setiadi, Op. Cit., hlm.10-11.
} 
Pengaruh..... Nida Amalia, Fatahuddin Aziz Siregar dan Aliman Syahuri Zein

keanggotaan merupakan kelompok primer seperti : keluarga, teman, tetangga, rekan kerja, yang berinteraksi dengan seseorang secara terus-menerus dan informal. Orang yang menjadi anggota kelompok sekunder, seperti kelompok keagamaan, profesi, dan asosiasi perdagangan, yang cenderung lebih formal dan membutuhkan interaksi yang tidak begitu rutin. ${ }^{17}$

Para pemasar berusaha mengidentifikasi kelompok referensi dan konsumen sasaran mereka. Orang umumnya sangat dipengaruhi oleh kelompok referensi mereka tiga cara. Pertama, kelompok referensi memperlihatkan pada seseorang perilaku dan gaya hidup baru. Kedua, mereka juga mempengaruhi sikap dan konsep jati diri seseorang karena orang tersebut umumnya ingin "menyesuaikan diri". ketiga, mereka menciptakan tekanan untuk menyesuaikan diri yang dapat mempengaruhi pilihan produk dan merk seseorang. ${ }^{18}$

(2) Keluarga

Keluarga dapat dibedakan menjadi dua dalam kehidupan membeli, yang pertama ialah : keluarga orientasi, yang merupakan orangtua seseorang. Dari orangtualah seseorang mendapatkan pandangan tentang agama, politik, ekonomi, dan merasakan ambisi pribadi nilai atau harga diri dan cinta. Keluarga prokreasi, yaitu pasangan hidup, anak- anak. seorang keluarga merupakan organisasi pembeli yang konsumen yang paling penting dalam suatu masyarakat dan telah diteliti secara intensif.

(3) Peran dan status

Seseorang berpartisipasi dalam banyak kelompok sepanjang hidupnya, keluarga, klub, organisasi. Posisi seseorang dalam setiap kelompok dapat diidentifikasi dalam peran dan status. ${ }^{19}$

c) Faktor pribadi

(1) Usia dan Tahapan Siklus Hidup

\footnotetext{
${ }^{17}$ Philip Kotler Dan Kevin Lane Keller, Manajemen Pemasaran, Edisi Kedua Belas Jilid I (Jakarta: PT. Macana Jaya Cemerlang, 2007), hlm. 217.

${ }^{18}$ Nugroho J Setiadi, Loc.Cit.

${ }^{19}$ Nugroho J Setiadi, Op. Cit., hlm.12.
} 
At-tijaroh Volume 3 No.2, Desember 2017

Orang membeli barang dan jasa yang berbeda-beda sepanjang hidupnya. Selera orang terhadap sesuatu juga berhubungan dengan usia. Konsumsi juga dibentuk oleh siklus hidup keluarga dan jumlah usia, gender dalam rumah tangga pada suatu saat.

(2) Pekerjaan

Pekerjaan seseorang juga mempengaruhi pola konsumsinya. Para pemasar berusaha mengidentifikasi kelompok pekerjaan yang memiliki minat diatas rata-rata terhadap produk dan jasa mereka. ${ }^{20}$

(3) Keadaan Ekonomi

Keadaan ekonomi seseorang terdiri dari pendapatan yang dapat dibelanjakan (tingkatnya, stabilitasnya, dan polanya), tabungan dan hartanya (termasuk persentase yang mudah dijadikan uang), kemampuan untuk meminjam dan sikap terhadap mengeluarkan lawan menabung.

(4) Gaya Hidup

Gaya hidup seseorang adalah pola hidup didunia yang diekspresikan oleh kegiatan, minat, dan pendapatan seseorang. Gaya hidup menggambarkan "seseorang secara keseluruhan" yang berinteraksi dengan lingkungan. Gaya hidup juga mencerminkan sesuatu dibali kelas sosial seseorang.

(5) Kepribadian dan konsep diri

Kepribadian adalah karakteristik psikologis yang berbeda dari setiap orang yang memandang responnya terhadap lingkungan yang relatif konsisten. Kepribadian merupakan suatu variabel yang sangat berguna untuk menganalisis perilaku konsumen. ${ }^{21}$

d) Faktor psikologi

(1) Motivasi

Dorongan dalam diri yang menggerakkan para konsumen memenuhi bayangan akan sebuah kebutuhan disebut motivasi.

(2) Persepsi

\footnotetext{
${ }^{20}$ Philip Kotler dan Kevin Lane Keller, Op. Cit., hlm. 222-223.

${ }^{21}$ Nugroho J Setiadi, Loc.Cit.
} 
Pengaruh..... Nida Amalia, Fatahuddin Aziz Siregar dan Aliman Syahuri Zein

Persepsi merupakan proses dimana seseorang memilih, mengorganisasikan, mengartikan masukan informasi untuk menciptakan suatu gambaran yang berarti didunia ini. Orang dapat memiliki persepsi yang berbeda dari objek yang sama karena adanya tiga proses presepsi, yaitu perhatian yang selekstif, gangguan yang selektif, mengingat kembali yang selektif. Hal ini berarti bahwa para pemasar harus bekerja keras agar pesan yang disampaikan diterima.

(3) Proses belajar

Proses belajar menjelaskan perubahan dalam perilaku seseorang yang timbul dari pengalaman.

(4) Kepercayaan

Kepercayaan adalah suatu gagasan deskriptif yang dimiliki seseorang terhadap sesuatu. ${ }^{22}$

\section{(5) Sikap}

Sikap adalah evaluasi berkelanjutan, perasaan, dan kecenderungan perilaku individu terhadapt sebuah objek atau gagasan.

\section{Pedoman Komunikasi Yang Baik}

American Manajemen Association (AMA) dalam buku karangan T. Handoko, telah menyusun sejumlah prinsip-pripsip komunikasi yang disebut "The Ten Commandment Of Good Communication" (Sepuluh Komunikasi Yang Baik). ${ }^{23}$ Pedoman ini disusun untuk meningkatkan efektifitas komunikasi organisasi yang secara ringkas adalah sebagai berikut :

a) Cari kejelasan gagasan-gagasan terlebih dahulu sebelum dikomunikasikan

b) Teliti tujuan sebenarnya setiap komunikasi

c) Pertimbangkan keadaan phisik dan manusia keseluruhan kapan saja komunikasi akan dilakukan

d) Konsultasikan dengan pihak-pihak lain bila perlu dalam perencanaan komunikasi

e) Perhatikan tekanan nada dan ekspresi lainnya sesuai isi dasar berita selama komunikasi.

\footnotetext{
${ }^{22}$ Nugroho J Setiadi, Op. Cit., hlm.13.

${ }^{23}$ T. Handoko, Op. Cit., hlm. 290.
} 
At-tijaroh Volume 3 No.2, Desember 2017

f) Ambil kesempatan bila timbul untuk mendapatkan segala sesuatu yang membantu atau umpan balik.

g) Ikuti terlebih dahulu komunikasi yang telah dilakukan.

h) Perhatikan konsistensi komunikasi.

i) Tindakan atau perbuatan harus mendorong komunikasi.

j) Jadilah pendengar yang baik, berkomunikasi tidak hanya untuk dimengerti tetapi untuk mengerti.

1) Hubungan Komunikasi Dengan Loyalitas Pelanggan

Dari sebuah komunikasi, seseorang dapat terpengaruh untuk menggunakan suatu produk dan memutuskan untuk berlangganan terhadap produk tersebut. Namun, dari komunikasi pula seseorang enggan untuk menggunakan suatu produk. Untuk itu, penting bagi perusahaan menjaga komunikasi dengan pelanggan. Karena pelanggan termasuk faktor terpenting dalam kelangsungan hidup perusahaan. Perusahaan yang baik tentu menciptakan sistem komunikasi yang baik pula, karena menyadari bahwa komunikasi akan turut menentukan keberhasilan kegiatan perusahaan. ${ }^{24}$

Hal inilah yang dilakukan oleh PT. Telkom Indonesia Cabang Padangsidimpuan dalam upaya membuat pelanggannya loyal. PT. Telkom Indonesia selalu berkomunikasi dengan ramah, sopan, dan memahami para pelanggannya sehingga pelanggan akan merasa aman dan percaya dalam memperoleh informasi yang diinginkan khususnya mengenai produk Indihome.

\section{Keluhan}

Keluhan muncul karena konsumen tidak mendapatkan hak-haknya setelah membayar sejumlah uang untuk mendapatkan produk barang atau jasa. ${ }^{25}$ Perbedaaan ini terkadang membawa kedalam situasi konflik. Dalam bisnis, tentu hal ini sangat tidak diharapkan. Keluhan merupakan masukan bagi organisasi/ lembaga bisnis. Adanya keluhan tersebut dengan sendirinya menunjukkan upaya untuk meningkatkan kualitas kehidupan itu belum dirasakan oleh pelanggan yang mengeluh. Konflik yang terjadi antara konsumen dengan perusahaan, dapat merupakan kesempatan untuk

\footnotetext{
${ }^{24}$ Amini, Perilaku Organisasi (Bandung : Citapustaka Media, 2004), hlm. 103.

${ }^{25}$ Yosal Iriantara, dkk., Komunikasi Bisnis (Jakarta : Universitas Terbuka, 2011), hlm. 9.4.
} 
Pengaruh...... Nida Amalia, Fatahuddin Aziz Siregar dan Aliman Syahuri Zein

membuktikan konsistensi janji yang diberikan kepada pelanggan melalui penyelesaiannya, serta informasi yang diperoleh dari kesediaan untuk mendiskusikan alasan terjadinya. Setiap organisasi yang berorientasi pada pelanggan perlu secara reguler memberikan kesempatan yang luas kepada para pelanggannya untuk menyampaikan saran, pendapat dan keluhan. Namun, para konsumen tidak selalu benar dan perusahaan tidak selalu salah sehingga kadang-kadang penjelasan yang sopan dapat menjernihkan kesalahpahaman. ${ }^{26}$

Secara umum, hak-hak konsumen mencakup: ${ }^{27}$
a) Hak memperoleh produk yang aman
b) Hak untuk mendapat informasi dan perlindungan
c) Hak untuk memilih produk
d) Hak untuk didengar oleh pemerintah
e) Hak untuk mendapat pendidikan konsumen

\section{METODE PENELITIAN}

Penelitian ini dilaksanakan di PT. Telkom Indonesia Cabang Padangsidimpuan yang beralamat di Jln. Patrice P. Lumumba No. 01 Kota Padangsidimpuan. Waktu penelitian dilakukan dari 30 Desember 2016 sampai dengan Juni 2017. Jenis penelitian yang dilakukan peneliti adalah kuantitatif. Penelitian kuantitatif adalah penelitian yang menggunakan data yang berbentuk angka atau data yang diangkakan. Dalam penelitian ini, populasi yang dimaksud adalah seluruh pelanggan yang menggunakan produk Indihome. Mulai bulan Januari 2016 hingga Desember 2016 dengan jumlah keseluruhan 3800 pelanggan. Sampel dihitung dengan rumus Slovin, jadi sampel dalam penelitian ini sebanyak 97,43 responden dan dibulatkan menjadi 97 responden. Metode pengambilan sampel dalam penelitian ini adalah Sampel Random Sampling, karena pengambilan anggota populasi dilakukan secara acak tanpa memperhatikan strata yang ada dalam populasi itu. ${ }^{28}$

Adapun Instrumen pengumpulan data yang digunakan dalam penelitian ini adalah sebagai berikut :

\footnotetext{
${ }^{26}$ Etta Mamang Sangadji dan Sopiah, Perilaku Konsumen: Pendekatan Praktis (Yogyakarta : Andi Publisher, 2014), hlm. 245.

${ }^{27}$ Yosal Iriantara, dkk. Op.Cit., hlm. 9.5.

${ }^{28}$ Sugiono, Statistika Untuk Penelitian Cetakan Sembilan (Bandung : Alfabeta, 2006), hlm. 57-58.
} 
At-tijaroh Volume 3 No.2, Desember 2017

1. Angket (kuesioner) merupakan salah satu teknik pengumpulan data dalam bentuk pertanyaan tertulis melalui sebuah daftar pertanyaan yang sudah dipersiapkan sebelumnya, dan harus diisi oleh responden. ${ }^{29}$

2. Teknik wawancara yaitu dengan melakukan tanya jawab secara langsung dengan pihakpihak yang terkait dalam penyediaan informasi atau data yang diperlukan dalam penelitian.

3. Dokumentasi merupakan catatan yang sudah berlaku, bisa dalam bentuk tulisan, gambar atau karya seni dari seseorang. Dokumen dapat berbentuk tulisan, misalnya catatan harian, sejarah kehidupan, peraturan dan lain-lain. Dokumentasi dilakukan untuk membuktikan bahwa penelitian ini benar-benar dilaksanakan dengan menyebar kuesioner kepada pelanggan.

Teknik analisis data meliputi: uji validitas, uji reliabilitas, analisis deskriptif, uji normalitas, uji linearitas dan uji asumsi klasik. Sementara itu untuk pengaruh hubungan antara variabel digunakan analisis regresi berganda dengan menghitung koefisien determinan, melakukan uji t dan uji F.

\section{HASIL PENELITIAN DAN PEMBAHASAN}

Untuk menguji data penelitian maka peneliti menggunakan program SPSS versi 22 sebagai berikut:

\section{Uji Validitas}

Uji validitas dilakukan untuk melihat apakah data yang ada valid atau tidak. Uji validitas dilakukan dengan membandingkan nilai $\mathbf{r}_{\text {hitung }}$ dengan nilai $\mathbf{r}_{\text {tabel. }}$ Dimana $\mathbf{r}_{\text {tabel }}$ dicari pada signifikansi $10 \%$ atau 0,1 dengan derajat kebebasan (df) $=\mathrm{n}-2$, dimana $\mathrm{n}=$ jumlah sampel, jadi $\mathrm{df}=97-2=95$, maka diperoleh $\mathbf{r}_{\text {tabel }}$ sebesar 0,168. Sedangkan $\mathbf{r}_{\text {hitung }}$ dapat dilihat pada hasil Corrected Item-Total Correlation. Jika $\mathrm{r}_{\text {hitung }}$ lebih besar dari $\mathrm{r}_{\text {tabel }}\left(\mathrm{r}_{\text {hitung }}>\mathrm{r}_{\text {tabel }}\right)$ dan nilai $\mathrm{r}$ positif maka butir pernyataan tersebut dikatakan valid.

Tabel 4.1

\section{Hasil Uji Validitas Variabel Komunikasi}

\footnotetext{
${ }^{29}$ Ibid., hlm. 95.
} 
Pengaruh...... Nida Amalia, Fatahuddin Aziz Siregar dan Aliman Syahuri Zein

\begin{tabular}{|c|c|c|c|}
\hline $\begin{array}{c}\text { Item } \\
\text { Pernyataan } \\
\end{array}$ & rhitung & rtabel & Keterangan \\
\hline Kmk1 & 0,671 & \multirow{12}{*}{$\begin{array}{c}\text { Instrumen valid, } \\
\text { jika } r_{\text {hitung }}>r_{\text {tabel }} \\
\text { dengan } \mathrm{df}=95 . \text { Pada } \\
\text { taraf signifikansi } \\
10 \% \text { sehingga } \\
\text { diperoleh } r_{\text {tabel }}= \\
0,168 .\end{array}$} & Valid \\
\hline Kmk2 & 0,636 & & Valid \\
\hline Kmk3 & 0,593 & & Valid \\
\hline Kmk4 & 0,520 & & Valid \\
\hline Kmk5 & 0,714 & & Valid \\
\hline Kmk6 & 0,568 & & Valid \\
\hline Kmk7 & 0,489 & & Valid \\
\hline Kmk8 & 0,633 & & Valid \\
\hline Kmk9 & 0,707 & & Valid \\
\hline Kmk10 & 0,615 & & Valid \\
\hline Kmk11 & 0,497 & & Valid \\
\hline Kmk12 & 0,690 & & Valid \\
\hline
\end{tabular}

Pada tabel 4.1 di atas dapat disimpulkan bahwa item pernyataan 1-12 untuk variabel komunikasi adalah valid. Berdasarkan $r_{\text {hitung }}>r_{\text {tabel }}$ dimana $r_{\text {tabel }}$ adalah 0,168. Sedangkan

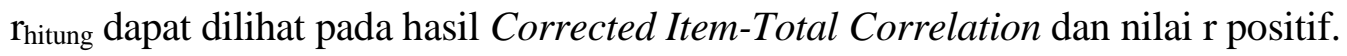

Tabel 4.2

Hasil Uji Validitas Variabel Komitmen

\begin{tabular}{|c|c|c|c|}
\hline $\begin{array}{c}\text { Item } \\
\text { Pernyataan }\end{array}$ & rhitung & $\mathbf{r}_{\text {tabel }}$ & Keterangan \\
\hline Kmn1 & 0,569 & \multirow{8}{*}{$\begin{array}{c}\text { Instrumen valid, } \\
\text { jika } \mathrm{r}_{\text {hitung }}>\mathrm{r}_{\text {tabel }} \\
\text { dengan } \mathrm{df}=95 . \\
\text { Pada taraf } \\
\text { signifikansi } 10 \% \\
\text { sehingga diperoleh } \\
\mathrm{r}_{\text {tabel }}=0,168 .\end{array}$} & Valid \\
\hline $\mathrm{Kmn} 2$ & 0,554 & & Valid \\
\hline Kmn3 & 0,475 & & Valid \\
\hline Kmn4 & 0,546 & & Valid \\
\hline Kmn5 & 0,610 & & Valid \\
\hline Kmn6 & 0,624 & & Valid \\
\hline Kmn7 & 0,323 & & Valid \\
\hline Kmn8 & 0,514 & & Valid \\
\hline
\end{tabular}

Pada tabel 4.2 di atas dapat disimpulkan bahwa item pernyataan 1-8 untuk variabel komitmen adalah valid. Berdasarkan $r_{\text {hitung }}>r_{\text {tabel }}$ dimana $r_{\text {tabel }}$ adalah 0,168. Sedangkan

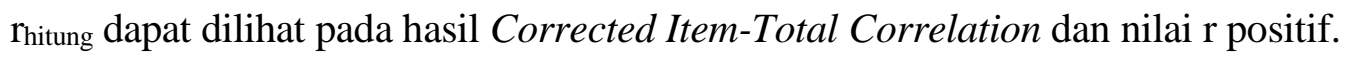


Tabel 4.3

Hasil Uji Validitas Variabel Penanganan Keluhan

\begin{tabular}{|c|c|c|c|}
\hline $\begin{array}{c}\text { Item } \\
\text { Pernyataan } \\
\end{array}$ & rhitung & rtabel & Keterangan \\
\hline Pnk1 & 0,624 & \multirow{12}{*}{$\begin{array}{c}\text { Instrumen } \\
\text { valid, jika } r \\
\text { hitung }>r_{\text {tabel }} \\
\text { dengan } d f=95 . \\
\text { Pada taraf } \\
\text { signifikansi } \\
\text { 10\% sehingga } \\
\text { diperoleh } r_{\text {tabel }} \\
=0,168 .\end{array}$} & Valid \\
\hline Pnk2 & 0,701 & & Valid \\
\hline Pnk3 & 0,703 & & Valid \\
\hline Pnk4 & 0,725 & & Valid \\
\hline Pnk5 & 0,785 & & Valid \\
\hline Pnk6 & 0,748 & & Valid \\
\hline Pnk7 & 0,605 & & Valid \\
\hline Pnk8 & 0,631 & & Valid \\
\hline Pnk9 & 0,649 & & Valid \\
\hline Pnk10 & 0,510 & & Valid \\
\hline Pnk11 & 0,524 & & Valid \\
\hline Pnk12 & 0,671 & & Valid \\
\hline
\end{tabular}

Pada tabel 4.3 di atas dapat disimpulkan bahwa item pernyataan 1-12 untuk variabel penanganan keluhan adalah valid. Berdasarkan $r_{h i t u n g}>r_{\text {tabel }}$ dimana $r_{\text {tabel }}$ adalah 0,168 .

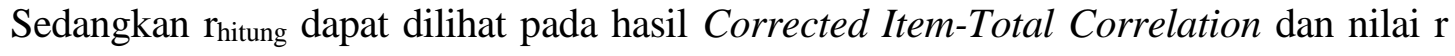
positif.

Tabel 4.4

Hasil Uji Validitas Variabel Loyalitas Pelanggan

\begin{tabular}{|c|c|c|c|}
\hline $\begin{array}{c}\text { Item } \\
\text { Pernyataan }\end{array}$ & rhitung & rtabel & Keterangan \\
\hline Lyls1 & 0,574 & \multirow{2}{*}{$\begin{array}{l}\text { Instrumen valid, } \\
\text { jika } r_{\text {hitung }}>\mathrm{r}_{\text {tabel }}\end{array}$} & Valid \\
\hline Lyls2 & 0,499 & & Valid \\
\hline
\end{tabular}


Pengaruh...... Nida Amalia, Fatahuddin Aziz Siregar dan Aliman Syahuri Zein

\begin{tabular}{|c|c|c|c|}
\hline Lyls3 & 0,330 & \multirow{10}{*}{$\begin{array}{c}\text { dengan } \mathrm{df}=95 \\
\text { Pada taraf } \\
\text { signifikansi } 10 \% \\
\text { sehingga diperoleh } \\
\mathrm{r}_{\text {tabel }}=0,168 .\end{array}$} & Valid \\
\hline Lyls4 & 0,392 & & Valid \\
\hline Lyls5 & 0,216 & & Valid \\
\hline Lyls6 & 0,600 & & Valid \\
\hline Lyls7 & 0,545 & & Valid \\
\hline Lyls8 & 0,593 & & Valid \\
\hline Lyls9 & 0,467 & & Valid \\
\hline Lyls10 & 0,593 & & Valid \\
\hline Lyls11 & 0,497 & & Valid \\
\hline Lyls12 & 0,596 & & Valid \\
\hline
\end{tabular}

Pada tabel 4.4 di atas dapat disimpulkan bahwa item pernyataan 1-12 untuk variabel loyalitas pelanggan adalah valid. Berdasarkan $r_{\text {hitung }}>r_{\text {tabel }}$ dimana $r_{\text {tabel }}$ adalah 0,168.

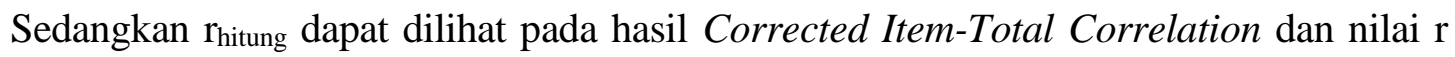
positif.

\section{Uji Reliabilitas}

Suatu instrumen dikatakan reliabel apabila nilai Cronbach's Alpha > 0,600. Uji reliabilitas dapat dilihat pada tabel berikut:

Tabel 4.5

\section{Hasil Uji Reliabilitas}

\begin{tabular}{|l|c|c|}
\hline \multicolumn{1}{|c|}{ Variabel } & Cronbach's Alpha & N of Items \\
\hline Komunikasi & 0,896 & 12 \\
\hline Komitmen & 0,809 & 8 \\
\hline Penanganan Keluhan & 0,915 & 12 \\
\hline Loyalitas Pelanggan & 0,823 & 12 \\
\hline
\end{tabular}

Dari hasil tabel 4.5 di atas menunjukkan bahwa Cronbach's Alpha untuk variabel komunikasi adalah 0,896 > 0,600 sehingga dapat disimpulkan bahwa pada variabel komunikasi $\left(\mathrm{X}_{1}\right)$ adalah reliabel. Selanjutnya, Cronbach's Alpha untuk variabel komitmen adalah 0,809 > 0,600 sehingga dapat disimpulkan bahwa pada variabel komitmen $\left(\mathrm{X}_{2}\right)$ adalah reliabel. Cronbach's Alpha untuk variabel penanganan keluhan adalah 0,915 > 0,600 sehingga dapat disimpulkan bahwa pada variabel penanganan keluhan $\left(\mathrm{X}_{3}\right)$ adalah reliabel. Cronbach's Alpha untuk variabel loyalitas pelanggan adalah 0,823>0,600 sehingga dapat disimpulkan bahwa pada variabel loyalitas pelanggan (Y) adalah reliabel. 
At-tijaroh Volume 3 No.2, Desember 2017

\section{Uji Statistik Deskriptif}

Statistik deskriptif adalah statistik yang digunakan untuk menganalisa data dengan cara mendeskripsikan atau menggambarkan data yang telah terkumpul sebagaimana adanya tanpa bermaksud membuat kesimpulan yang berlaku umum atau generalisasi. Uji statistik deskriptif dapat dilakukan dengan cara mencari mean, minimum, maksimum dan standard deviation dapat dilihat pada tabel di bawah ini:

Tabel 4.6

\section{Hasil Uji Statistik Deskriptif}

Descriptive Statistics

\begin{tabular}{|l|r|r|r|r|r|}
\hline & N & Minimum & Maximum & Mean & Std. Deviation \\
\hline KOMUNIKASI & 97 & 32 & 60 & 48,70 & 6,217 \\
KOMITMEN & 97 & 20 & 40 & 31,69 & 3,933 \\
KELUHAN & 97 & 32 & 60 & 47,26 & 7,049 \\
LOYALITAS & 97 & 33 & 60 & 46,41 & 5,567 \\
Valid N (listwise) & 97 & & & & \\
& & & & \\
\hline
\end{tabular}

Berdasarkan tabel 4.6 di atas dapat dilihat bahwa variabel komunikasi dengan jumlah data $(\mathrm{N})$ sebanyak 97 mempunyai nilai mean sebesar 48,70 dengan nilai mimimum 32 dan nilai maksimum 60 serta standar deviasinya sebesar 6,217. Variabel komitmen dengan jumlah data $(\mathrm{N})$ sebanyak 97 mempunyai nilai mean sebesar 31,69 dengan nilai mimimum 20 dan nilai maksimum 40 serta standar deviasinya sebesar 3,933. Variabel penanganan keluhan dengan jumlah data $(\mathrm{N})$ sebanyak 97 mempunyai nilai mean sebesar 47,26 dengan nilai mimimum 32 dan nilai maksimum 60 serta standar deviasinya sebesar 7,049. Variabel loyalitas dengan jumlah data (N) sebanyak 97 mempunyai nilai mean sebesar 46,41 dengan nilai mimimum 33 dan nilai maksimum 60 serta standar deviasinya sebesar 5,567.

\section{Uji Normalitas}

Uji normalitas dilakukan untuk menguji apakah dalam model regresi variabel terikat dan variabel bebas mempunyai distribusi normal atau tidak. Pada grafik histogram jika distribusi data tidak menceng ke kiri atau ke kanan maka distribusi data tersebut normal. 
Pada grafik Normal P-P Plot Of Regression Standardized Residual jika titik-titik menyebar disekitar dan mengikuti garis diagonal maka nilai residual tersebut sudah normal. Adapun hasil uji normalitas dalam penelitian ini sebagai berikut

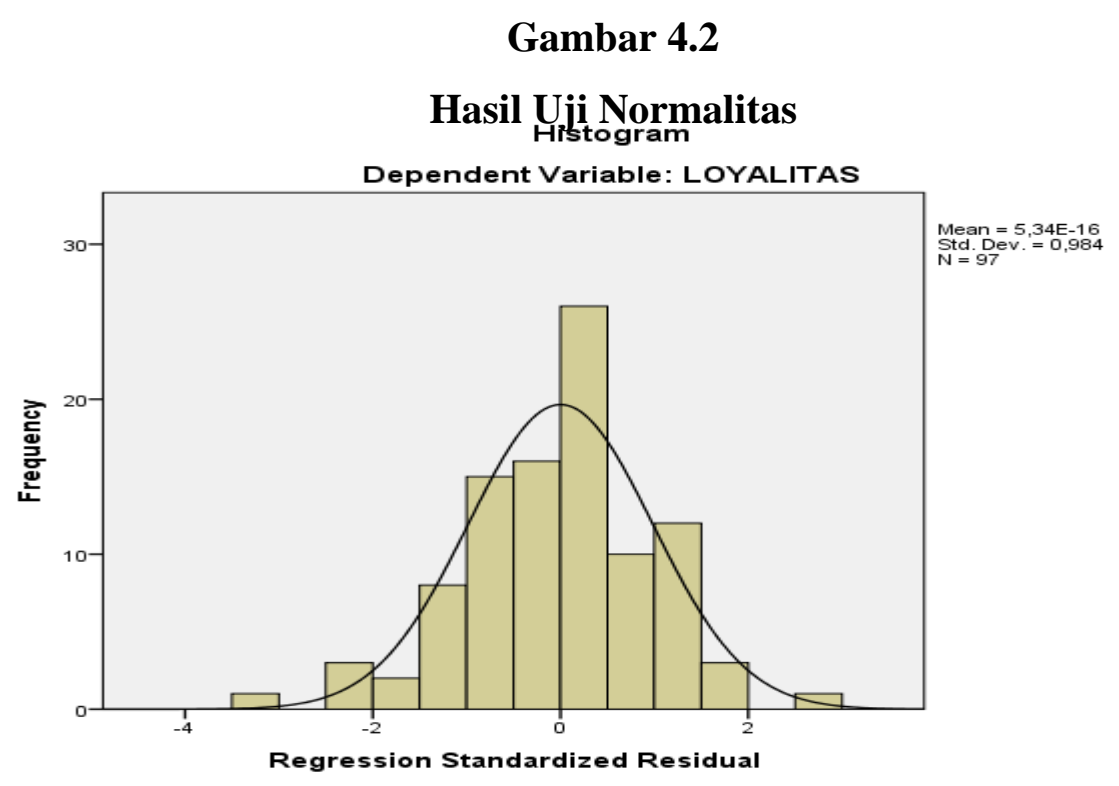

Berdasarkan grafik histogram di atas distribusi data tidak menceng ke kiri atau ke kanan maka dapat disimpulkan bahwa pola distribusi data tersebut normal.

Gambar 4.3

Hasil Uji Normalitas

Normal P-P Plot of Regression Standardized Residual

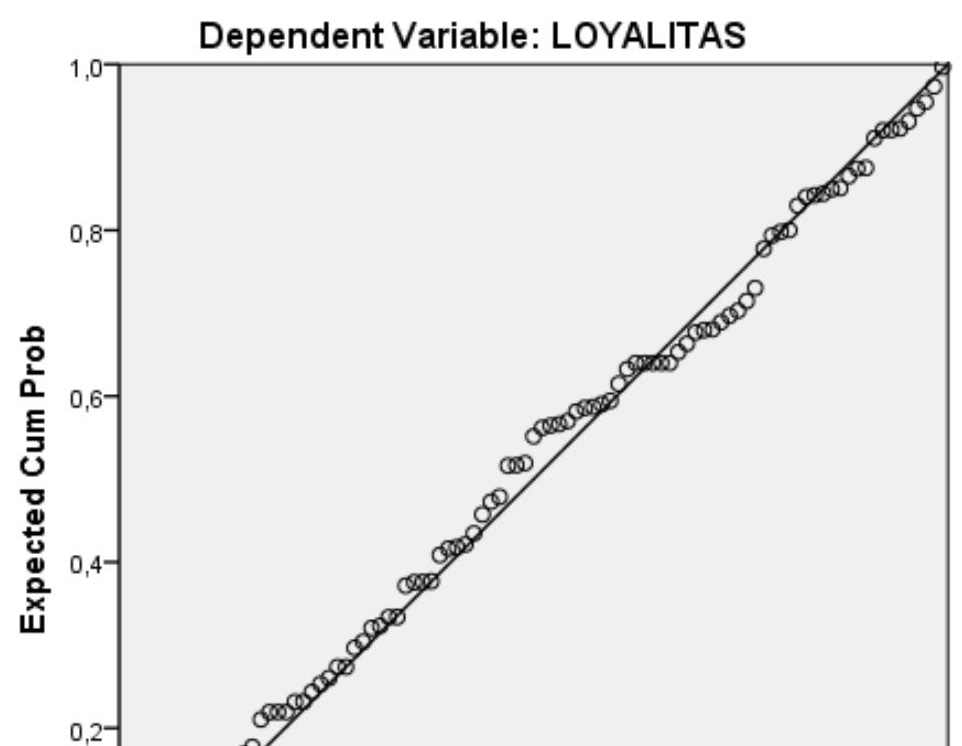


At-tijaroh Volume 3 No.2, Desember 2017

Berdasarkan grafik Normal P-P Plot Of Regression Standardized Residual di atas dapat diketahui bahwa titik-titik menyebar disekitar garis diagonal dan mengikuti garis diagonal maka dapat disimpulkan bahwa nilai residual tersebut sudah normal.

\section{Uji Linieritas}

Uji linieritas bertujuan untuk mengetahui apakah antara variabel bebas dengan variabel terikat mempunyai hubungan yang linier atau tidak secara signifikan. Variabel dikatakan mempunyai hubungan yang linier jika nilai Sig. > 0,1 dan jika nilai Sig. < 0,1 maka dinyatakan tidak linier.

a. Uji Linieritas Komunikasi dengan Loyalitas

Tabel 4.7

Hasil Uji Linieritas Kmk dengan Lyls

\begin{tabular}{|c|c|c|c|c|c|c|c|}
\hline & & & $\begin{array}{l}\text { Sum of } \\
\text { Squares }\end{array}$ & Df & $\begin{array}{l}\text { Mean } \\
\text { Square }\end{array}$ & $\mathbf{F}$ & Sig. \\
\hline \multirow{6}{*}{$\begin{array}{l}\text { LOYALITAS } \\
* \\
\text { KOMUNIKA } \\
\text { SI }\end{array}$} & Between & (Combined) & 1644,521 & 26 & 63,251 & 3,327 &, 000 \\
\hline & Groups & Linearity & 1215,849 & 1 & 1215,849 & 63,945 &, 000 \\
\hline & & Deviation from & & & & & \\
\hline & & Linearity & & & & & \\
\hline & \multicolumn{2}{|c|}{ Within Groups } & 1330,984 & 70 & 19,014 & & \\
\hline & \multicolumn{2}{|l|}{ Total } & 2975,505 & 96 & & & \\
\hline
\end{tabular}


Pengaruh..... Nida Amalia, Fatahuddin Aziz Siregar dan Aliman Syahuri Zein

Berdasarkan tabel 4.7 di atas nilai Sig. sebesar 0,601. Jadi, dapat disimpulkan nilai Sig. > 0,1 $(0,601>0,1)$ menunjukkan bahwa hubungan antara variabel komunikasi dengan variabel loyalitas adalah linier.

b. Uji Linieritas Komitmen dengan Loyalitas

\section{Tabel 4.8}

Hasil Uji Linieritas Kmn dengan Lyls

\begin{tabular}{|c|c|c|c|c|c|c|c|}
\hline & & & $\begin{array}{l}\text { Sum of } \\
\text { Squares }\end{array}$ & df & $\begin{array}{l}\text { Mean } \\
\text { Square }\end{array}$ & $\mathbf{F}$ & Sig. \\
\hline \multirow{5}{*}{$\begin{array}{l}\text { LOYALITAS * } \\
\text { KOMITMEN }\end{array}$} & Between & (Combined) & 1729,855 & 18 & 96,103 & 6,018 &, 000 \\
\hline & Groups & Linearity & 1409,011 & 1 & 1409,011 & 88,229 & ,000 \\
\hline & & $\begin{array}{l}\text { Deviation from } \\
\text { Linearity }\end{array}$ & 320,844 & 17 & 18,873 & 1,182 & ,299 \\
\hline & Within $\mathrm{Gl}_{\mathrm{r}}$ & & 1245,650 & 78 & 15,970 & & \\
\hline & Total & & 2975,505 & 96 & & & \\
\hline
\end{tabular}

Berdasarkan tabel 4.8 di atas nilai Sig. sebesar 0,299. Jadi, dapat disimpulkan nilai Sig. > 0,1 (0,299 > 0,1) menunjukkan bahwa hubungan antara variabel komitmen dengan variabel loyalitas adalah linier.

c. Uji Linieritas Penanganan Keluhan dengan Loyalitas

Tabel 4.9

Hasil Uji Linieritas Pnk dengan Lyls

\begin{tabular}{|c|c|c|c|c|c|c|c|}
\hline & & & $\begin{array}{l}\text { Sum of } \\
\text { Squares }\end{array}$ & df & $\begin{array}{l}\text { Mean } \\
\text { Square }\end{array}$ & $\mathbf{F}$ & Sig. \\
\hline \multirow{5}{*}{$\begin{array}{l}\text { LOYALITAS * } \\
\text { KELUHAN }\end{array}$} & Between & (Combined) & 1500,561 & 25 & 60,022 & 2,889 & ,000 \\
\hline & Groups & Linearity & 1026,295 & 1 & 1026,295 & 49,403 &, 000 \\
\hline & & $\begin{array}{l}\text { Deviation from } \\
\text { Linearity }\end{array}$ & 474,265 & 24 & 19,761 & ,951 & ,537 \\
\hline & Within $\mathrm{Gr}$ & & 1474,944 & 71 & 20,774 & & \\
\hline & Total & & 2975,505 & 96 & & & \\
\hline
\end{tabular}

Berdasarkan tabel 4.9 di atas nilai Sig. sebesar 0,537. Jadi, dapat disimpulkan nilai Sig. > 0,1 $(0,537>0,1)$ menunjukkan bahwa hubungan antara variabel penanganan keluhan dengan variabel loyalitas adalah linier. 
At-tijaroh Volume 3 No.2, Desember 2017

\section{Uji Asumsi Klasik}

\section{a. Uji Multikolinearitas}

Suatu model regresi dinyatakan bebas dari multikolinearitas adalah jika nilai Tolerance lebih besar dari 0,1 (nilai Tolerance > 0,1) dan jika nilai VIF lebih kecil dari 10 (nilai VIF < 10). Hasil uji multikolinearitas penelitian ini sebagai berikut:

Tabel 4.10

Hasil Uji Multikolinearitas

\begin{tabular}{|ll|r|c|}
\hline \multirow{2}{*}{ Model } & \multicolumn{2}{|c|}{ Collinearity Statistics } \\
\cline { 3 - 4 } & & \multicolumn{1}{|c|}{ Tolerance } & \multicolumn{1}{c|}{ VIF } \\
\hline 1 & (Constant) & & \\
& KOMUNIKASI &, 385 & 2,599 \\
& KOMITMEN &, 463 & 2,159 \\
& KELUHAN &, 566 & 1,766 \\
& &
\end{tabular}

Berdasarkan tabel 4.10 di atas dapat diketahui nilai Tolerance dari variabel komunikasi adalah 0,385 >0,1, variabel komitmen adalah 0,463>0,1, variabel penanganan keluhan adalah 0,217>0,1, variabel penanganan keluhan adalah 0,566 $>0,1$. Jadi, dapat disimpulkan nilai Tolerance dari ketiga variabel di atas lebih besar dari 0,1 (nilai Tolerance > 0,1) sehingga bebas dari multikolinearitas.

Selanjutnya berdasarkan nilai VIF dari variabel komunikasi adalah 2,599 < 10, variabel komitmen adalah 2,159 < 10, variabel penangan keluhan adalah 1,766 < 10. Jadi, dapat disimpulkan nilai VIF dari ketiga variabel di atas lebih kecil dari 10 (nilai VIF < 10) sehingga bebas dari multikolinearitas.

\section{b. Uji Heteroskedastisitas}

Model regresi yang baik adalah yang tidak terjadi heteroskedastisitas. Suatu model regresi dikatakan tidak terjadi heteroskedastisitas apabila titik-titik pada 
Pengaruh...... Nida Amalia, Fatahuddin Aziz Siregar dan Aliman Syahuri Zein

scatterrplot regresi tidak membentuk pola tertentu seperti menyebar di atas dan di bawah angka 0 pada sumbu Y. Hasil uji heteroskedastisitas sebagai berikut:

\section{Gambar 4.4}

\section{Hasil Uji Heteroskedastisitas}

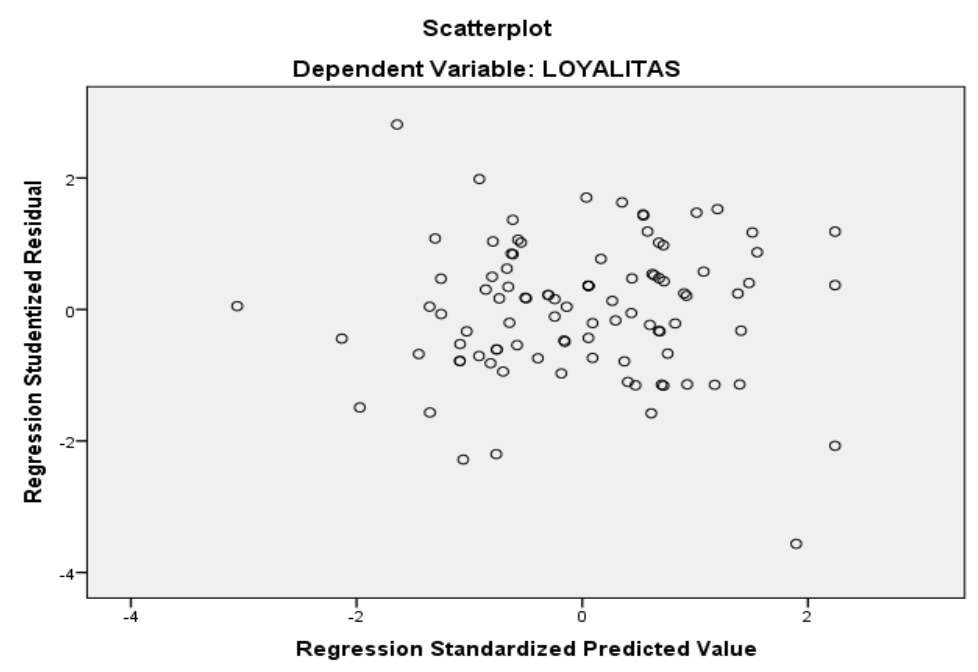

Berdasarkan gambar di atas dapat dilihat bahwa titik-titik tidak membentuk suatu pola tertentu. Titik-titik menyebar di atas dan di bawah angka 0 pada sumbu Y. Jadi, dapat disimpulkan bahwa model regresi terbebas dari heteroskedastisitas.

\section{Uji Analisis Regresi Linier Berganda}

Analisis regresi linier berganda yang digunakan dalam penelitian ini untuk mengetahui pengaruh relationship marketing yang terdiri dari faktor komunkasi $\left(\mathrm{X}_{1}\right)$, komitmen 
At-tijaroh Volume 3 No.2, Desember 2017

$\left(\mathrm{X}_{2}\right)$, penanganan keluhan $\left(\mathrm{X}_{3}\right)$, terhadap loyalitas pelanggan $(\mathrm{Y})$. Hasilnya dapat dilihat pada tabel di bawah ini:

Tabel 4.11

Hasil Uji Analisis Regresi Linier Berganda

\begin{tabular}{|c|c|c|c|}
\hline \multirow{2}{*}{\multicolumn{2}{|c|}{ Model }} & \multicolumn{2}{|c|}{$\begin{array}{l}\text { Unstandardized } \\
\text { Coefficients }\end{array}$} \\
\hline & & B & Std. Error \\
\hline \multirow[t]{4}{*}{1} & (Constant) & 10,633 & 3,407 \\
\hline & KOMUNIKASI & , 152 & , 101 \\
\hline & KOMITMEN & ,614 & , 145 \\
\hline & KELUHAN & , 189 & ,073 \\
\hline
\end{tabular}

Berdasarkan tabel 4.11 di atas dapat dilihat pada kolom Unstandardized Coefficients bagian kolom B, maka persamaan analisis regresi linier berganda dalam penelitian ini adalah:

$$
\begin{aligned}
& \text { Lyls }=\alpha+\mathrm{b}_{1} \mathrm{Kmk}+\mathrm{b}_{2} \mathrm{Kmn}+\mathrm{b}_{3} \text { Pnk }+\mathrm{e} \\
& \text { Lyls }=10,633+0,152 \mathrm{Kmk}+0,614 \mathrm{Kmn}+0,189 \mathrm{Pnk}+\mathrm{e} \\
& \text { Keterangan: } \\
& \text { Lyls = Loyalitas } \\
& \alpha \quad=\text { Konstanta } \\
& \mathrm{b}_{1}, \mathrm{~b}_{2}, \mathrm{~b}_{3}=\text { Koefisien regresi linier berganda } \\
& \mathrm{Kmk} \quad=\text { Komunikasi } \\
& \mathrm{Kmn} \quad=\text { Komitmen } \\
& \text { Pnk = Penanganan keluhan } \\
& \text { e }=\text { Standard error term }
\end{aligned}
$$

Persamaan regresi tersebut dapat dijelaskan sebagai berikut:

a. Konstanta sebesar 10,633, artinya apabila variabel komunikasi, komitmen, penanganan keluhan dianggap konstan atau 0 maka loyalitas pelanggan nilainya sebesar 10,633 satuan. 
Pengaruh..... Nida Amalia, Fatahuddin Aziz Siregar dan Aliman Syahuri Zein

b. Koefisien regresi variabel komunikasi sebesar 0,152, artinya apabila tingkat komunikasi meningkat 1 satuan maka loyalitas pelanggan meningkat sebesar 10,785 satuan. Koefisien bernilai positif artinya terjadi hubungan positif antara komunikasi dengan loyalitas pelanggan, semakin naik faktor komunikasi maka semakin meningkat loyalitas pelanggan.

c. Koefisien regresi variabel komitmen sebesar 0,614, artinya apabila tingkat kepuasan pelanggan meningkat 1 satuan maka loyalitas pelanggan meningkat sebesar 11,247 satuan. Koefisien bernilai positif artinya terjadi hubungan positif antara komitmen dengan loyalitas pelanggan, semakin naik faktor komitmen maka semakin meningkat loyalitas pelanggan.

d. Koefisien regresi variabel penanganan keluhan sebesar 0,189, artinya apabila tingkat penanganan keluhan pelanggan meningkat 1 satuan maka loyalitas pelanggan meningkat sebesar 10,822 satuan. Koefisien bernilai positif artinya terjadi hubungan positif antara penanganan keluhan dengan loyalitas pelanggan, semakin naik faktor penanganan keluhan maka semakin meningkat loyalitas pelanggan.

\section{Uji Koefisien Determinasi $\left(\mathbf{R}^{2}\right)$}

Koefisien determinasi $\left(\mathrm{R}^{2}\right)$ pada intinya mengukur seberapa jauh model dalam menerangkan variasi variabel terikat. Nilai koefisien determinasi adalah di antara nol dan satu.

Tabel 4.12

Hasil Uji Koefisien Determinasi

\begin{tabular}{|l|r|r|r|r|}
\hline Model & R & R Square & \multicolumn{1}{c|}{$\begin{array}{c}\text { Adjusted R } \\
\text { Square }\end{array}$} & $\begin{array}{c}\text { Std. Error of } \\
\text { the Estimate }\end{array}$ \\
\hline 1 &, $740^{\mathrm{a}}$ &, 547 &, 533 & 3,806 \\
\hline
\end{tabular}

Dari tabel 4.12 di atas dapat diketahui bahwa nilai $\mathrm{R}^{2}$ sebesar 0,547. Menunjukkan bahwa 54,7\% variabel komunikasi, komitmen, penanganan keluhan, mempengaruhi loyalitas pelanggan sedangkan 45,3\% sisanya dipengaruhi atau dijelaskan oleh variabel lain yang tidak dibahas dalam penelitian ini.

\section{Uji Hipotesis}

\section{a. Uji Signifikansi Parsial (Uji t)}


At-tijaroh Volume 3 No.2, Desember 2017

Uji statistik t pada dasarnya menunjukkan seberapa jauh pengaruh satu variabel bebas secara individual dalam menerangkan variasi variabel terikat. Ketentuan dalam uji t adalah: jika thitung $<\mathrm{t}_{\text {tabel }}$ maka $\mathrm{H}_{0}$ diterima dan $\mathrm{H}_{\mathrm{a}}$ ditolak sedangkan jika $t_{\text {hitung }}>\mathrm{t}_{\text {tabel }}$ maka $\mathrm{H}_{0}$ ditolak dan $\mathrm{H}_{\mathrm{a}}$ diterima dan jika nilai Sig. $<0,1$ maka $\mathrm{H}_{0}$ ditolak dan $\mathrm{H}_{\mathrm{a}}$ diterima.

Tabel 4.13

Hasil Uji Signifikansi Parsial (Uji t)

\begin{tabular}{|ll|r|r|}
\hline & & & \\
Model & & T & \multicolumn{2}{|c|}{ Sig. } \\
\hline 1 & (Constant) & 3,121 &, 002 \\
& KOMUNIKASI & 1,511 &, 134 \\
& KOMITMEN & 4,230 &, 000 \\
& KELUHAN & 2,575 &, 012 \\
\hline
\end{tabular}

Untuk tabel dicari pada $\alpha=10 \%: 2=5 \%$ (uji dua sisi) dengan derajat kebebasan (df)=n-k-1, dimana $n=j u m l a h$ sampel dan $\mathrm{k}=$ jumlah variabel independen, jadi $\mathrm{df}=97$ 3-1=93. Dengan pengujian dua sisi (signifikansi=0,05), maka diperoleh $t_{\text {tabel }}$ sebesar 1,661 .

Berdasarkan hasil uji signifikansi parsial (uji t) tabel 4.13 di atas dapat dilihat bahwa pada variabel komunikasi memiliki thitung sebesar 1,551 dan $t_{\text {tabel }}$ sebesar 1,661 sehingga $t_{\text {hitung }}<\mathrm{t}_{\text {tabel }}(1,511<1,661)$ maka $\mathrm{H}_{\mathrm{a}}$ ditolak. Selanjutnya, pada variabel komunikasi memiliki nilai Sig. sebesar 0,134 sehingga nilai Sig. > 0,1 $(0,134>0,1)$ maka $\mathrm{H}_{\mathrm{a}}$ ditolak. Jadi, dapat disimpulkan bahwa secara parsial komunikasi tidak mempunyai pengaruh terhadap loyalitas pelanggan.

Pada variabel komitmen memiliki thitung sebesar 4,230 dan tabel sebesar 1,661 sehingga $t_{\text {hitung }}>t_{\text {tabel }}(4,230>1,661)$ maka $H_{a}$ diterima. Selanjutnya, pada variabel komitmen memiliki nilai Sig. sebesar 0,000 sehingga nilai Sig. $<0,1(0,000<0,1)$ maka $\mathrm{H}_{\mathrm{a}}$ diterima. Jadi, dapat disimpulkan bahwa secara parsial komitmen mempunyai pengaruh terhadap loyalitas pelanggan. 
Pengaruh..... Nida Amalia, Fatahuddin Aziz Siregar dan Aliman Syahuri Zein

Pada variabel penanganan keluhan memiliki $t_{\text {hitung }}$ sebesar 2,525 dan $t_{\text {tabel }}$ sebesar 1,661 sehingga $t_{\text {hitung }}>t_{\text {tabel }}(2,525>1,661)$ maka $H_{a}$ diterima. Selanjutnya, pada variabel penanganan keluhan memiliki nilai Sig. sebesar 0,012 sehingga nilai Sig. < $0,1(0,012<0,1)$ maka $\mathrm{H}_{\mathrm{a}}$ diterima. Jadi, dapat disimpulkan bahwa secara parsial penanganan keluhan mempunyai pengaruh terhadap loyalitas pelanggan.

\section{b. Uji Signifikansi Simultan (Uji F)}

Uji statistik F pada dasarnya menunjukkan apakah semua variabel bebas yang dimasukkan dalam model mempunyai pengaruh secara bersama-sama terhadap variabel terikat. Ketentuan dalam uji $\mathrm{F}$ adalah: jika $\mathrm{F}_{\text {hitung }}<\mathrm{F}_{\text {tabel }}$ maka $\mathrm{H}_{0}$ diterima dan $\mathrm{H}_{\mathrm{a}}$ ditolak sedangkan jika $\mathrm{F}_{\text {hitung }}>\mathrm{F}_{\text {tabel }}$ maka $\mathrm{H}_{0}$ ditolak dan $\mathrm{H}_{\mathrm{a}}$ diterima dan jika nilai Sig. $<0,1$ maka $\mathrm{H}_{0}$ ditolak dan $\mathrm{H}_{\mathrm{a}}$ diterima.

Tabel 4.14

Hasil Uji Signifikansi Simultan (Uji F)

\begin{tabular}{|c|c|c|c|c|c|}
\hline Model & $\begin{array}{l}\text { Sum of } \\
\text { Squares }\end{array}$ & Df & Mean Square & $\mathbf{F}$ & Sig. \\
\hline $\begin{array}{ll}1 & \text { Regression } \\
\text { Residual } \\
\text { Total }\end{array}$ & $\begin{array}{r}1628,466 \\
1347,039 \\
2975,505\end{array}$ & $\begin{array}{r}3 \\
93 \\
96\end{array}$ & $\begin{array}{r}542,822 \\
14,484\end{array}$ & 37,477 &, $000^{\mathrm{b}}$ \\
\hline
\end{tabular}

$\mathrm{F}_{\text {tabel }}$ untuk signifikansi $\alpha=0,1$ dengan regression (df 1) adalah 3 dan residual (df 2) adalah 93 (berasal dari total-regresion), maka hasil yang diperoleh untuk $\mathrm{F}_{\text {tabel }}$ sebesar 2,14.

Dari hasil uji signifikansi simultan (uji F) tabel 4.14 di atas bahwa nilai $F_{\text {hitung sebesar }}$ 37,477 sedangkan $F_{\text {tabel }}$ sebesar 2,14 sehingga $F_{\text {hitung }}>F_{\text {tabel }}(37,477>2,14)$ maka $\mathrm{H}_{\mathrm{a}}$ diterima. Selanjutnya, untuk nilai Sig. sebesar 0,000 sehingga nilai Sig. $<0,1(0,000$ $<0,1)$ maka $\mathrm{H}_{\mathrm{a}}$ diterima. Jadi, dapat disimpulkan bahwa secara simultan komunikasi, 
At-tijaroh Volume 3 No.2, Desember 2017

komitmen dan penanganan keluhan mempunyai pengaruh terhadap loyalitas pelanggan.

\section{Pembahasan Hasil Penelitian}

Penelitian ini berjudul Pengaruh Relationship marketing Terhadap Loyalitas Pelanggan Produk Indihome Pada PT. Telkom Indonesia Cabang Padangsidimpuan. Dari hasil analisis data yang dilakukan pada penelitian ini dengan menggunakan bantuan program SPSS versi 22 diketahui bahwa:

1. Persamaan analisis regresi linear berganda diperoleh sebagai berikut: Lyls $=\alpha+b_{1} K m k$ $+\mathrm{b}_{2} \mathrm{Kmn}+\mathrm{b}_{3} \mathrm{Pnk}+\mathrm{e}$

Lyls $=10,633+0,152 \mathrm{Kmk}+0,614 \mathrm{Kmn}+0,189 \mathrm{Pnk}+\mathrm{e}$

a. Konstanta sebesar 10,633, artinya apabila variabel komunikasi, komitmen, penanganan keluhan dianggap konstan atau 0 maka loyalitas pelanggan nilainya sebesar 10,633 .

b. Koefisien regresi variabel komunikasi sebesar 0,152 artinya apabila tingkat komunikasi meningkat 1 satuan maka loyalitas pelanggan meningkat sebesar 10,785 satuan. Koefisien bernilai positif artinya terjadi hubungan positif antara komunikasi dengan loyalitas pelanggan, semakin naik komunikasi maka semakin meningkat loyalitas pelanggan.

c. Koefisien regresi variabel komitmen sebesar 0,614 artinya apabila tingkat kepuasan pelanggan meningkat 1 satuan maka loyalitas pelanggan meningkat sebesar 11,247 satuan. Koefisien bernilai positif artinya terjadi hubungan positif antara komitmen dengan loyalitas pelanggan, semakin naik komitmen maka semakin meningkat loyalitas pelanggan.

d. Koefisien regresi variabel penanganan keluhan sebesar 0,189 artinya apabila tingkat penanganan keluhan pelanggan meningkat 1 satuan maka loyalitas pelanggan meningkat sebesar 10,822 satuan. Koefisien bernilai positif artinya terjadi hubungan positif antara penanganan keluhan dengan loyalitas pelanggan, semakin naik penanganan keluhan maka semakin meningkat loyalitas pelanggan. 
Pengaruh...... Nida Amalia, Fatahuddin Aziz Siregar dan Aliman Syahuri Zein

2. Hasil uji koefisien determinasi faktor komunikasi, komitmen, penanganan keluhan mampu mempengaruhi loyalitas pelanggan sebesar 54,7\% sedangkan sisanya 45,3\% dipengaruhi oleh faktor lain.

3. Secara parsial variabel komunikasi tidak mempunyai pengaruh terhadap loyalitas pelanggan dengan nilai $t_{\text {hitung }}<t_{\text {tabel }}(1,511<1,661)$ dan nilai Sig. $>\alpha(0,134>0,1)$. Hal ini disebabkan setiap orang memiliki persepsi yang berbeda terhadap objek yang sama atau kita bisa memandang situasi yang sama dengan cara yang berbeda. Termasuk cara komunikasi yang dilakukan oleh PT. Telkom Indonesia yang dipandang berbeda oleh setiap pelanggan. Hal ini didukung teori menurut Philip Kotler dan Kevin Lane Keller menyatakan bahwa: ${ }^{30}$

"Persepsi tidak hanya bergantung pada stimuli fisik tetapi juga pada stimuli yang berhubungan dengan lingkungan sekitar dan keadaan individu tersebut”.

4. Secara parsial variabel komitmen mempunyai pengaruh terhadap loyalitas pelanggan dengan nilai $t_{\text {hitung }}>t_{\text {tabel }}(4,230>1,661)$ dan nilai Sig. $<\alpha(0,000<0,1)$. Hasil dari penelitian ini didukung teori Edy Sutrisno yang menyatakan bahwa: ${ }^{31}$

"Semakin nyaman dan tinggi manfaat yang dirasakan pelanggan, maka semakin tinggi pula komitmen pelanggan terhadap perusahaan."

Hasil penelitian ini juga didukung dengan hasil penelitian terdahulu dari skripsi Faris Mujaddid Adinugroho, menyatakan dalam penelitiannya: ${ }^{32}$

"Komitmen berpengaruh positif dan signifikan terhadap loyalitas pelanggan minimarket Indomaret. Hal ini berarti komitmen pelanggan merupakan salah satu faktor penting dalam mensukseskan hubungan baik dan jangka panjang antara pelanggan dengan minimarket Indomaret sehingga loyalitas pelanggan akan tercapai."

Oleh karena itu, penting bagi PT. Telkom Indonesia untuk menjaga komitmen dengan pelanggan. Karena ketika perusahaan memiliki komitmen yang kuat untuk

\footnotetext{
${ }^{30}$ Philip Kotler dan Kevin Lane Keller, Op.Cit., hlm. 228.

${ }^{31}$ Edy Sutrisno, Loc. Cit.

${ }^{32}$ Faris Mujaddid Adi Nugroho, "Pengaruh Kepercayaan Pelanggan, Komitmen Pelanggan dan Komunikasi Word Of Mouth Terhadap Loyalitas Pelanggan Minimarket” (Skripsi, Universitas Negeri Yogyakarta, 2015), hlm. 96.
} 
At-tijaroh Volume 3 No.2, Desember 2017

mempertahankan pelanggan maka diharapkan pelanggan juga akan memiliki komitmen yang sama karena adanya manfaat ekonomi yang terjadi dalam kedua belah pihak.

5. Secara parsial variabel penanganan keluhan mempunyai pengaruh terhadap loyalitas pelanggan dengan nilai $t_{\text {hitung }}>t_{\text {tabel }}(2,525>1,661)$ dan nilai Sig. $<\alpha(0,012<0,1)$. Hasil dari penelitian ini didukung dengan hasil penelitian terdahulu dari skripsi Aulia Yumi Rosda, menyatakan dalam penelitiannya: ${ }^{33}$

"Variabel penanganan keluhan mempunyai pengaruh yang signifikan terhadap loyalitas nasabah PT. Bank Negara Indonesia Kantor Cabang Sudirman Pekanbaru."

Serta didukung oleh teori Etta Mamang Sangadji dan Sopiah yang mengemukakan bahwa $:^{34}$

"Solusi untuk keluhan pelanggan merupakan bagian yang paling penting dalam masalah kehilangan pelanggan. Jika perusahaan berhasil memberi solusi terbaik dari keluhan pelanggan, sebanyak 98\% konsumen akan tetap bersedia menjadi pelanggan dan tidak pindah ke perusahaan lain.”

Sehingga, agar pelanggan produk Indihome tetap loyal maka PT. Telkom Indonesia harus mampu memberikan solusi terbaik yang tepat dan adil menguntungkan kedua bela pihak (win-win solution) untuk setiap keluhan pelanggan.

6. Secara simultan variabel komunikasi, komitmen, penanganan keluhan, mempunyai pengaruh terhadap loyalitas pelanggan dengan $F_{\text {hitung }}>F_{\text {tabel }}(37,477>2,14)$ dan nilai Sig. $<0,1(0,000<0,1)$. Hasil dari penelitian ini didukung dengan hasil penelitian terdahulu dari skripsi Sasanti Herdina Murti, menyatakan dalam penelitiannya $:^{35}$

"Adanya pengaruh yang positif dan signifikan dari relationship marketing yang terdiri dari kepercayaan, komitmen, komunikasi, serta penanganan keluhan terhadap loyalitas konsumen Katering Prima Semarang."

\footnotetext{
${ }^{33}$ Aulia Yumi Rosda, “Analisis Pengaruh Kepercayaan, Komunikasi, Komitmen, Dan Penanganan Keluhan Terhadap Loyalitas Nasabah di PT. Bank Bank Negara Indonesia Syariah Kantor Cabang Sudirman Pekanbaru” (Skripsi, Universitas Islam Riau, 2015), hlm. 96.

${ }^{34}$ Etta Mamang Sangadji dan Sopiah, Op.Cit., hlm. 246.

${ }^{35}$ Sasanti Herdina Murti, Op. Cit., hlm. 102.
} 
Pengaruh...... Nida Amalia, Fatahuddin Aziz Siregar dan Aliman Syahuri Zein

\section{KESIMPULAN DAN SARAN}

\section{Kesimpulan}

Berdasarkan hasil penelitian dan pembahasan, maka kesimpulan yang dapat diperoleh sebagai berikut:

1. Persamaan analisis regresi linear berganda diperoleh sebagai berikut: Lyls $=\alpha+b_{1}$ $\mathrm{Kmk}+\mathrm{b}_{2} \mathrm{Kmn}+\mathrm{b}_{3} \mathrm{Pnk}+\mathrm{e}$

Lyls $=10,633+0,152 \mathrm{Kmk}+0,614 \mathrm{Kmn}+0,189 \mathrm{Pnk}+\mathrm{e}$

a. Konstanta sebesar 10,633, artinya apabila variabel komunikasi, komitmen, penanganan keluhan dianggap konstan atau 0 maka loyalitas pelanggan nilainya sebesar 10,633 .

b. Koefisien regresi variabel komunikasi sebesar 0,152 artinya apabila tingkat komunikasi meningkat 1 satuan maka loyalitas pelanggan meningkat sebesar 10,785 satuan. Koefisien bernilai positif artinya terjadi hubungan positif antara komunikasi dengan loyalitas pelanggan, semakin naik komunikasi maka semakin meningkat loyalitas pelanggan.

c. Koefisien regresi variabel komitmen sebesar 0,614 artinya apabila tingkat kepuasan pelanggan meningkat 1 satuan maka loyalitas pelanggan meningkat sebesar 11,247 satuan. Koefisien bernilai positif artinya terjadi hubungan positif antara komitmen dengan loyalitas pelanggan, semakin naik komitmen maka semakin meningkat loyalitas pelanggan.

d. Koefisien regresi variabel penanganan keluhan sebesar 0,189 artinya apabila tingkat penanganan keluhan pelanggan meningkat 1 satuan maka loyalitas pelanggan meningkat sebesar 10,822 satuan. Koefisien bernilai positif artinya terjadi hubungan positif antara penanganan keluhan dengan loyalitas pelanggan, semakin naik penanganan keluhan maka semakin meningkat loyalitas pelanggan.

2. Hasil uji secara parsial (uji t) dapat disimpulkan bahwa variabel komunikasi tidak mempunyai pengaruh terhadap loyalitas pelanggan produk Indihome pada PT. Telkom Indonesia Cabang Padangsidimpuan dengan nilai $t_{\text {hitung }}<\mathrm{t}_{\text {tabel }}(1,511<1,661)$ dan nilai Sig. $>\alpha(0,134<0,1)$.

3. Hasil uji secara parsial (uji t) dapat disimpulkan bahwa variabel komitmen mempunyai pengaruh terhadap loyalitas pelanggan produk Indihome pada PT. Telkom Indonesia 
At-tijaroh Volume 3 No.2, Desember 2017

Cabang Padangsidimpuan dengan nilai $t_{\text {hitung }}>\mathrm{t}_{\text {tabel }}(4,230>1,661)$ dan nilai Sig. $<\alpha$ $(0,000<0,1)$.

4. Hasil uji secara parsial (uji t) dapat disimpulkan bahwa variabel penanganan keluhan mempunyai pengaruh terhadap loyalitas pelanggan produk Indihome pada PT. Telkom Indonesia Cabang Padangsidimpuan dengan nilai $t_{\text {hitung }}<t_{\text {tabel }}(2,525<1,661)$ dan nilai Sig. $>\alpha(0,012>0,1)$.

5. Hasil uji secara simultan (uji F) dapat disimpulkan bahwa secara bersama-sama komunikasi, komitmen dan penanganan keluhan mempunyai pengaruh terhadap loyalitas pelanggan produk Indihome pada PT. Telkom Indonesia Cabang Padangsidimpuan dengan $F_{\text {hitung }}>F_{\text {tabel }}(37,477>2,14)$ dan nilai Sig. $<0,1(0,000<0,1)$.

\section{Saran}

Adapun saran yang bisa diberikan setelah melakukan penelitian ini, sebagai berikut:

1. Penelitian ini menunjukkan pentingnya pengembangan faktor komunikasi, komitmen dan penanganan keluhan sebagai faktor-faktor yang perlu dipertimbangkan dalam upaya meningkatkan dan mempertahankan loyalitas pelanggan. Maka, disarankan untuk pihak PT. Telkom Indonesia Cabang Padangsidimpuan agar lebih mengembangkan faktorfaktor tersebut sebab semakin tingginya tingkat persaingan di dunia teknologi dan semakin dinamisnya kebutuhan dan keinginan para pelanggan. Faktor komitmen merupakan faktor utama dalam meningkatkan pemakaian produk Indihome. Apabila PT. Telkom Indonesia sudah tidak mendapatkan kepercayaan maka akan banyak pelanggan tidak memakai bahkan memutuskan hubungan dengan PT. Telkom Indonesia. Adanya dorongan rasa nyaman, aman, dan manfaat lain yang didapat oleh pelanggan akan membuat loyal kepada perusahaan. Semakin nyaman dan tinggi manfaat yang dirasakan pelanggan, maka semakin tinggi pula komitmen pelanggan terhadap perusahaan. Adanya penanganan keluhan yang ditangani dengan adil menunjukkan konsistensi janji yang diberikan kepada pelanggan. Untuk itu solusi yang dihasilkan haruslah memperoleh solusi yang menguntungkan kedua belah pihak (winwin solution). PT. Telkom Indonesia juga harus mampu berkomunikasi kepada pelanggan secara jelas, ramah, dan sopan. 
Pengaruh...... Nida Amalia, Fatahuddin Aziz Siregar dan Aliman Syahuri Zein

2. Untuk peneliti selanjutnya agar dapat mengembangkan penelitian ini dengan meneliti faktor-faktor lain yang dapat mempengaruhi loyalitas pelanggan dan dapat melakukan perluasan sampel dalam penelitian selanjutnya, mengingat sampel yang digunakan dalam penelitian ini hanya pada produk Indihome pada PT. Telkom Indonesia Cabang Padangsidimpuan.

\section{DAFTAR PUSTAKA}

Basu Swastha Dharmesta dan T. Hani Handoko, Manajemen Pemasaran Bank: Analisis Perilaku Konsumen, Yogyakarta: BPFE Yogyakarta, 2016.

Buchari Alma dan Donni Juni Priansa, Syariah Marketing, Bandung : Cv. Alfabeta, 2009.

Departemen Agama, Alqur'an Terjemahan Dan Asbabun Nuzul, Surakarta :CV. Al-Hanan, 2009.

Etta Mamang Sangadji dan Sopiah, Perilaku Konsumen, Pendekatan Praktis, Yogyakarta : Andi Publisher, 2014.

Herry Sutanto dan Khaerul Umam, Manajemen Pemasaran Bank Syariah, Bandung: Pustaka Setia, 2013.

M. Quraish Shihab, Tafsir Al-Misbah, Jakarta: Lentera Hati, 2002

Morissan, Periklanan : Komunikasi Pemasaran Terpadu, Jakarta: Kencana, 2010.

Nugroho J Setiadi, Perilaku Konsumen, Jakarta: Kencana, 2010.

Patricia Sorce, "Relationship Marketing Strategy", Research. New York: Rochester Institute of Technology, 2002.

Philip Kotler Dan Kevin Lane Keller, Manajemen Pemasaran, Edisi Kedua Belas Jilid I, Jakarta: PT.Macana Jaya Cemerlang, 2007.

Tettiana Dongoran, Supervisor Plasa PT. Telkom Indonesia Cabang Padangsidimpuan wawancara di Plasa Telkom Padangsidimpuan, 29 Oktober 2016.

T. Handoko, Manajemen, Edisi Kedua Cet: Kesepuluh, Yogyakarta: BPFE, 2009.

Sugiono, Statistika Untuk Penelitian, Bandung: Alfabeta, 2006.

Website Resmi PT Telkom Indonesia, https://my.telkom.co.id/ 
At-tijaroh Volume 3 No.2, Desember 2017

Yosal Iriantara, dkk., Komunikasi Bisnis, Jakarta : Universitas Terbuka, 2011. 